\title{
Особенности ценностно-смысловой сферы людей с разным уровнем приобщённости к музыкальной культуре
}

В данной статье рассмотрены основные научно-психологические подходы к проблеме личностных особенностей людей с разным уровнем принятия музыки как индивидуальной ценности, выявлена актуальность данной темы, приведены данные эмпирического исследования личностных особенностей людей с разным уровнем приобщённости к музыкальной культуре.

Ключевые слова: психология искусства, психология музыки, ценностносмысловая сфера личности.

В настоящее время музыка играет важную роль в повседневной жизни миллионов людей. Определение её феноменов и формулирование её законов занимает центральное место, в научной работе многих учёных. Социологи, психологи, искусствоведы, музыкальные педагоги и просто обычные люди, - все они в той или иной мере подвержены постоянно меняющимися музыкальным тенденциям. Отчасти эти тенденции и подтолкнули психологов на более детальное изучение взаимосвязи человека и музыки и выделение из общей психологии самобытной отрасли - музыкальной психологии или психологии музыки. Область музыкальной психологии является пограничной между сферой искусства и сферой науки о человеке [1]. Следует отметить, что в настоящее время, в обществе нарастает потребность в музыкальной составляющей его культуры. И долг искусства, отраслью которого является музыка - помочь обществу пережить трудности, давая надежду и моральную поддержку. Вообще, говоря о современной культуре, можно констатировать наличие некоторых изменений. Как структурно, так и функционально «Когда-то искусство требовалось, чтобы перебить невыносимую жизненность смерти, теперь - чтобы перебить невыносимую смертную скуку жизни»[4, с. 225]. Проблеме понимания того, что есть музыка, рассмотренная сквозь призму психологии, были посвящены теоретические разработки выдающихся музыкантов, психологов и педагогов - Алексеева А., Бочкарева Л.Л., Лосева А.Ф., Тарасова Г.С., Когана Г.М., Нейгауза Г.Г., Петрушина В.И., Федорова Е.Е. и др. Можно вспомнить и классические для психологии имена зарубежных учёных - В. Вундт, Г. Гельмголц, К. Штумпф, Т. Адорно и др.

Несмотря на определенную разработанность этой темы, существующий научный плюрализм не позволяет считать эту тему досконально изученной. Ныне мы встречаемся с настоящим взлетом музыкально-психологических изысканий. Вышли в свет программы по психологии для музыкальных вузов, хрестоматии, альманахи, защищен ряд диссертационных работ (И.Е. Виноградова, Я.Т. Жакупова, Е.А. Глазкова). Появились психологи музыки, которая понимается ими как отрасль психологии искусства, изучающая воздействие музыки на человека и его активную музыкальную деятельность [3]. Музыкальная психология исследует проблемы 
процессов формирования, развития и определения музыкальных способностей; психологических механизмов сочинения, исполнения, восприятия и обучения музыке; применения музыки как массового средства коммуникации (в концертах, спектаклях, кино, на телевидении, радиовещании); влияние функциональной музыки на производительность труда; лечебного воздействия музыки на человека; профессиональной деятельности музыканта: его обучение, воспитание профессиональных и артистических качеств (умение общаться с публикой и воздействовать на нее); эстетической, нравственной и воспитательной роли музыки в формировании подрастающих поколений; влияния музыки на повышение творческого потенциала личности. Одним из направлений музыкальной психологии является психология музыкальной деятельности, которая изучает основные ее виды: слушание (восприятие), исполнение, сочинение и преподавание музыки. Особый аспект - изучение ценностных особенностей музыкантов: специфика, креативная направленность, выявление индивидуальных центраций. Проблема изучения ценностно-смысловой сферы личности в настоящее время приобретает все более комплексный характер, являясь предметом различных социальных дисциплин, и представляет собой важную область исследований, расположенную на стыке различных отраслей знания о человеке - философии, социологии, психологии, педагогики. Теоретический анализ и исследования ценностно-смысловой сферы на различных уровнях создали необходимость использования понятий и методологических оснований смежных научных дисциплин. Ценностно-смысловая сфера личности включает в себя два основных компонента - ценностные ориентации и систему личностных смыслов [2]. Оба компонента неразрывно связаны с понятием личность, поскольку тесно соприкасаются с изучением человеческого поведения и побуждений. Как общенаучные понятия они способствует объединению исследуемых объектов различных наук.

В следствии этого, психологическая практика требует осмысления теоретических установок психологии музыки. Анализ исследований, посвящённых изучению ценностно-смысловой сферы музыкантов, показал, что проблема процесса создания музыкального образа, актуализирующегося ценностно-смысловым содержанием музыканта, как субъекта музыкального переживания, изучена недостаточно. Именно ценностно-смысловая сфера определяет особенности инициации креативного процесса в музыкальной деятельности, опосредуя специфические, свойственные именно данной личности музыкальные образы. Возникающее противоречие между усилением потребности в стимуляции эмоционально-эстетического развития и отсутствием реальных технологий достижения определило проблему исследования, результаты которого изложены в настоящей статье.

Для практического выполнения поставленных целей и задач исследования были использованы несколько групп методов анализа и диагностики: определение жизненных ценностей личности (Must-тест) (П.Н. Иванов, Е.Ф. Колобова); диагностика реальной структуры ценностных ориентаций личности (С.С. Бубнова); экспресс-диагностика социальных ценностей личности; тест смысложизненных 
ориентаций (СЖО) (Д.А. Леонтьев); методика «Ценностные ориентации» М. Рокича; анкета-опросник (К.В. Бондарь, И.В. Абакумова).

Всего в исследовании добровольно приняли участие 150 человек. Из них 75 женщин и 75 мужчин в возрасте от 18 до 30 лет. Все испытуемые принимали участие в эксперименте по своему желанию. В первой группе представлены музыканты города Ростова-на-Дону, регулярно гастролирующие и участвующие в музыкальных мероприятиях. Вторую группу соствавили люди, не являющиеся музыкантами, но регулярно посещающие концерты и другие музыкальные мероприятия, имея богатую палитру музыкальных пристрастий. В третью группу вошли люди, не имеющие музыкальных пристрастий и индифферентно относящиеся к музыкальной культуре.

Для начала нами была разработана, опробированно и валидизированна анкета-опросник. Основываясь на данных корреляционного анализа (ранговый коэф. корр. Спирмена), можно признать, что пункты анкеты с номерами 1, 2, 4, 5, $8,10,11,14$ обладают высокой степенью прогностической валидности ( $p<0.08)$. Полученные данные позволяют говорить о высоком уровне осмысления и понимания музыкальной культуры, как части современного искусства, а полученные значимые различия указывают на то, что люди с разным уровнем приобщённости к музыкальной культуре могут иметь различные смысложизненные ориентации, образ мира и способы взаимодействия с ним.

Затем были полученны и интерпритированны данные всех субшкал методик. Далее, основываясь на корреляционном анализе (ранговый коэф. корр. Спирмена) были выявлены значимые различия по следующим субшкалам:

СжО:

Результат: Слуш.>Неслуш.>Муз $(\mathrm{R}=-0,304, \mathrm{p}<0,05)$

Диагностика реальной структуры ценностных ориентаций личности (С.C. Бубнова):

Поиск и наслаждение прекрасным Слуш>Муз $>$ Неслуш $(R=0,295, p<0,05)$.

Определение жизненных ценностей личности(Must-тест) (П.Н. Иванов, Е.Ф. Колобова):

Привлекательность Слуш>Неслуш $(\mathrm{R}=-0,255, \mathrm{p}<0,05)$

Экспресс - диагностика социальных ценностей личности:

Значимых различий по данной методике выявлено не было.

Методика «ценностные ориентации» М.Рокича:

Терминальные ценности:

Интересная работа Неслуш>Слуш>Муз $(\mathrm{R}=-0,233, \mathrm{p}<0,05)$

Красота природы и искусства Муз>Слуш $>$ Неслуш $(\mathrm{R}=0,408, \mathrm{p}<0,05)$

Материально обеспеченная жизнь Неслуш>Слуш $>$ Муз $(R=-0,353, p<0,05)$

Творчество Муз>Слуш>Неслуш $(R=0,581, p<0,05)$

Уверенность в себе Неслуш>Слуш>Муз $(R=-0,303, p<0,05)$

Инструментальные ценности:

Образованность Муз $>$ Неслуш $>$ Слуш $(\mathrm{R}=0,254, \mathrm{p}<0,05)$

Эффективность в делах Слуш>Неслуш $>$ Муз $(\mathrm{R}=-0,373, \mathrm{p}<0,05)$. 
В целом, на основании данных корреляционного анализа Спирмена можно отметить, что количество полученных нами достоверно значимых различий, позволяют говорить о подтверждении ряда гипотез.

В последствии нами была поставлена задача конкретизировать психологическим содержанием понятие приобщённость к музыкальной культуре, и выявить влияние ценностей и смысложизнненых ориентаций на её уровень. Дискриминантный анализ значимых различий показал, что с ошибкой не более $15 \%$ наши гипотезы нашли подтверждение в нашем исследовании, а основываясь на полученные эмпирические данные можно говорить, о присущих каждой группе индивидуально значимых ценностях и смысложизненных ориентациях.

На рисунках №№ 1,2,3 приведены данные дискриминантного анализа «музыкантов», «слушателей» и «неслушателей».

\section{РИсУнок № 1 «НЕСЛУШАТЕЛИ»}

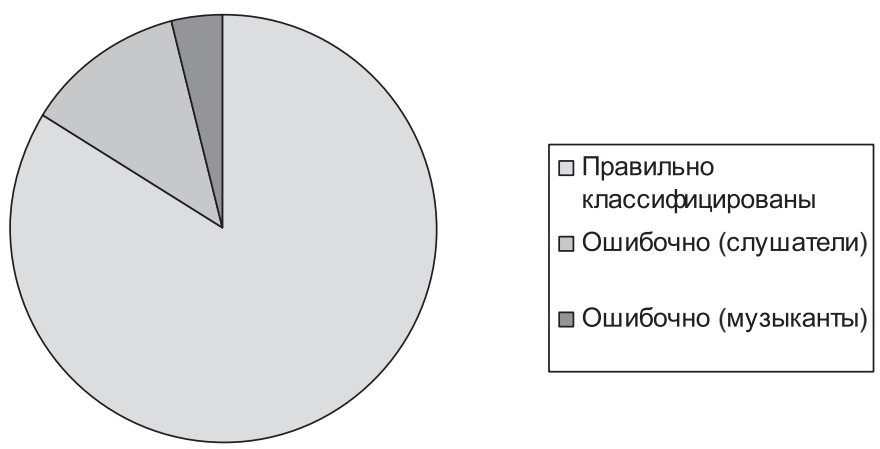

\begin{tabular}{|l|l|}
\hline Правильно классифицированы & 42 \\
\hline Ошибочно (слушатели) & 6 \\
\hline Ошибочно (музыканты) & 2 \\
\hline
\end{tabular}

Из рисунка видно, что, основываясь на полученных данных, мы с 80 \% вероятностью правильно дифференцировали «неслушателей» от «слушателей» и «музыкантов». Основываясь на данных, полученных при помощи корреляционного анализа Спирмена и Дискриминантного анализа, мы можем говорить о следующих особенностях данной группы: люди, не приобщённые к музыкальной культуре оказываются более удовлетворенными пройденным отрезком жизненного пути, его продуктивностью и осмысленностью, по отношению к музыкантам. В меньшей степени эти люди нацелены на эстетическую сторону искусства, творчества и природы. Куда более значимыми для них являются материальные ценности и карьерные достижения. Менее остальных нацелены на саморазвитие, образование и собственную пивлекательность. 


\section{Рисунок № 2«СЛУШАТЕЛИ»}

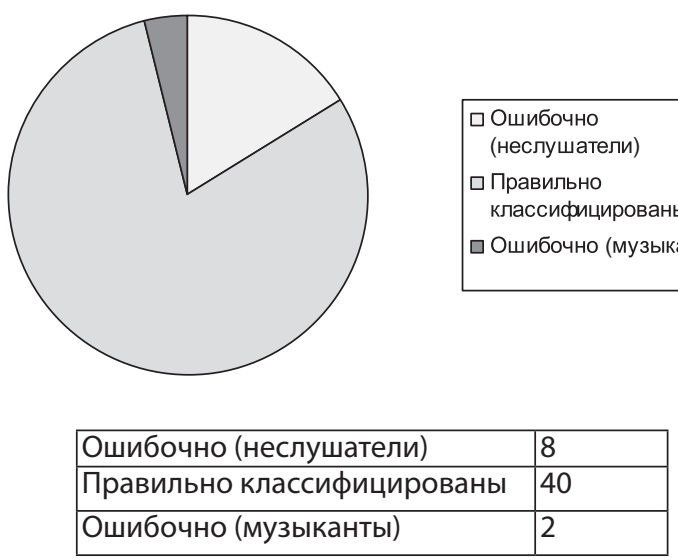

Из рисунка видно, что, основываясь на полученных данных, мы с 84 \% вероятностью правильно дифференцировали «слушателей» от «музыкантов» и неслушателей». Основываясь на данных, полученных при помощи корреляционного анализа Спирмена и Дискриминантного анализа, мы можем говорить о следующих особенностях данной группы: люди, находящиеся в постоянном контакте с искусством, более приобщённые к музыкальной культуре оказываются более удовлетворенными пройденным отрезком жизненного пути, его продуктивностью и осмысленностью, нежели музыканты. В большей степени слушатели нацелены на эстетическую составляющую своей жизни: искусство, творчество, красоту природы.

\section{Рисунок № 3«МУЗЫКАНТЫ»}

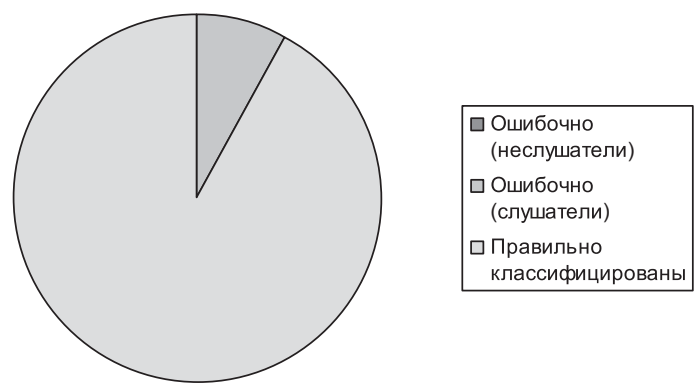

\begin{tabular}{|l|l|}
\hline Ошибочно (неслушатели) & 0 \\
\hline Ошибочно (слушатели) & 4 \\
\hline Правильно классифицированы & 46 \\
\hline
\end{tabular}


Из рисунка видно, что, основываясь на полученных данных, мы с $92 \%$ вероятностью правильно дифференцировали «музыкантов» от «слушателей» и неслушателей». Основываясь на данных, полученных при помощи корреляционного анализа Спирмена и Дискриминантного анализа, мы можем говорить о следующих особенностях данной группы: люди, непосредственно вовлечённые в процесс создания и исполнения музыкальных произведений, как культурно-эстетических ценностей, показывают неудовлетворенность пройденным отрезком жизненного пути, его продуктивностью и осмысленностью. Именно этот факт, по нашему мнению, является оновной «движущей силой», определяющей особенности инициации креативного процесса в музыкальной деятельности, опосредуя специфические, свойственные именно данной личности музыкальные образы. В подтверждение гипотезы о том, что уровень приобщённости к музыкальной культуре может оказывать существенное влияние на смысловые центрации и жизненные приоритеты, можно отметить данные методики «Ценностные ориентации» Милтона Рокича: для музыкантов специфичным является направленность на образованность, творчество, красоту природы и искусства. Неспецифичными являются такие жизненные приоритеты как уверенность в себе, эффективность в делах, интересная работа и материально обеспеченная жизнь.

Основываясь на всё проведённое нами исследование, можно сформулировать психологическое наполнение понятия «приобщённость к музыкальной культуре».

Приобщённость к музыкальной культуре - объективный критерий интенсивности взаимодействия личности с музыкальной культурой и цивилизацией музыкальных образов.

Приобщённость к музыкальной культуре - субъективный критерий ориентированный на уровень ценностно-смыслового отношения к музыкальной культуре определяющийся ценностно-смысловым принятием в процессе аутогенной рефлексии.

В результате проведенного исследования были сформулированы следующие выводы.

1. Уровень приобщённости к музыкальной культуре влияет на ценностносмысловые особенности людей.

2. Люди с разным уровнем приобщённости к музыкальной культуре имеют различные смысло-жизненные ориентации, образ мира и способы взаимодействия с ним.

3. Уровень приобщённости к музыкальной культуре оказывает существенное влияние на смысловые центрации и жизненные приоритеты.

4.Уровень приобщённости к музыкальной культуре определяется субъективным и объективным критерием, при этом объективный критерий - это интенсивность взаимодействия личности с музыкальной культурой и цивилизацией музыкальных образов. Субъективный-это критерий ориентированный 
на уровень ценностно-смыслового отношения к музыкальной культуре определяющийся ценностно-смысловым принятием в процессе аутогенной рефлексии.

\section{Литература}

1. Петрушин В.И. Музыкальная психология: Учебное пособие для вузов. 2-е изд. М. Академический Проект, Трикста, 2008. - 400 с

2. Серый А.В, Яницкий М.С. Ценностно-смысловая сфера личности / Учебное пособие. - Кемерово: Кемеровский государственный университет, 1999. - 92 с.

3. Старчеус М.С. Музыкальная психология: Хрестоматия. - М., 1992.

4. Шкуратов В.А. Искусство экономной смерти. Сотворение видеомира. - Рн/Д: Наррадигма, 2006. - 400 с. 